\title{
A biomass gasification system for synthesis gas from the new method
}

\author{
Li-Qun Wang ${ }^{1}$, Yu-Huan Dun' ${ }^{2}$, Heng Tang ${ }^{3}$, Tong-Zhang Wang ${ }^{3}$ \\ ${ }^{1}$ Department of Energy and Power Engineering, Jiangsu University, Zhenjiang, China; thwlq2000@163.com \\ ${ }^{2}$ Department of Energy and Power Engineering, Jiangsu University, Zhenjiang, China; dunyuhuan1985@126.com \\ ${ }^{3}$ Department of Energy and Power Engineering, Jiangsu University, Zhenjiang, China
}

Received 27 June 2009; revised 20 July 2009; accepted 22 July 2009.

\begin{abstract}
This paper describes a single fluidized bed by the two-step gasification of the working method, process and biomass and coal co-gasification by a certain proportion of the results of a typical run. The results show that the biomass gasification technology for raw materials has a wide adaptability, the tar content in the gas is less than $10 \mathrm{mg} / \mathrm{m}^{3}$, component in it ,the $\mathrm{H}_{2}+\mathrm{CO}>70 \%$, $\mathrm{H}_{2} / \mathrm{C} \approx 1 \sim 2$,especially suitable for biomass from hydrogen, synthetic alcohol fuel, is a promising approach.
\end{abstract}

Keywords: Fuidized Bed; Double Bed; Biomass; Synthesis Gas; Co-Gasification; Steam Gasification

\section{INTRODUCTION}

In the growing depletion of traditional fossil fuel, mankind is facing increasing environmental pollution cases, countries around the world are actively developing renewable energy sources. And other types of biomass energy have unparalleled advantages, it can be stored and is the only low-carbon renewable energy, with lower sulfur and nitrogen, small environmental pollution and zero emissions of greenhouse gases, it is mature technology and can be made of the excellent transport liquid fuel alternative energy, automobile and caused consumers a wide range of great importance, as well as a major agricultural country, Brazil, the United States, Europe, China and other areas of the development of biomass energy in the walk in the world. At present, the production of bio-ethanol and bio-diesel used as a substitute for gasoline and diesel is a hot research and development, the process mainly through the use of bio-fermentation starch or sugar of biomass into ethanol.

Brazil, mainly use sugar cane as raw material, while the United States and China, with corn as the main raw material. With the development of biomass fuel and ex- pansion, as well as international food prices, the international community to the best alternative to new energy sources of oil-bio-fuel ethanol opposition is growing. Causing people to question the professionals to reflect on the current bio-fuel ethanol production is the vast majority of food crops as raw materials, in the long run with the scale of restrictions and non-sustainability of lignocellulose raw materials to the second generation of bio-fuel ethanol is the future key to large-scale alternative to oil. The Chinese government approval in 2006 no longer agree the grain as raw materials to fuel ethanol production companies, shifting to second-generation bio-fuels research and development. The United States and the European Union has drawn up development plans, increase the second- generation bio-fuel ethanol technology, the pace of study. However, current technology development, fuel cellulosic ethanol technology in the pretreatment of raw materials and reduce the cost of a major breakthrough in enzyme takes time. U.S. Department of Energy is expected to cellulose ethanol fuel in 2012 may be about to get a major breakthrough, and a number of research institutions in Europe think that in 2015 to 2020. In addition to fuel ethanol, some companies have chosen to research and development of biomass gasification production of alcohol fuel, biodiesel, Fischer-Topsch synthesis of diesel and other key issues of technology, the application of reserves for the future technology, laying the foundation for the market to seize the future. The use of biomass gasification method to high-quality biomass into fuel, and bio-technology comparison with a broad range of sources of raw materials (agriculture, forestry, waste, garbage, etc.) into efficient, production intensity, and almost no waste, easy to mass production, the production process of the environmental impact of small, less greenhouse gas emissions. At present, biomass gasification system for synthesis gas from the basic approach is to use non- $\mathrm{N}_{2}$ gasification agent or change the way the heating biomass pyrolysis and gasification, gas composition obtained for $\mathrm{H}_{2}, \mathrm{CO}, \mathrm{CH}_{4}$ and $\mathrm{CO}_{2}$, the specific methods of oxygen gasification, steam gasification and fluidized-bed gasification method dou- 
ble. Gasification as a result of oxygen-free $\mathrm{N}_{2}$ gas in the gas, a higher calorific value gas, the $\mathrm{CO}, \mathrm{H}_{2}$ with a high level, $\mathrm{CH}_{4}$ low, due to oxygen gasification free to adjust the reaction temperature, the reaction completely and higher gas production, gasification higher efficiency, the technology is mature, simple, stable operation and suitable for large- scale production, as a result of oxygen equipment, investment and operating costs are higher, it is difficult to adapt to storage and transportation of biomass resources, the high cost of dispersed and difficult to mass production characteristics. The water vapor is a strong endothermic reaction gasification, biomass pyrolysis and gasification temperature above $800^{\circ} \mathrm{C}$ need to have a higher reaction rate, it is generally difficult to achieve this temperature steam requirements, so less gas production, gasification and low efficiency. The advantage is to form $\mathrm{H}_{2}, \mathrm{CH}_{4}$ more, $\mathrm{CO}_{2}, \mathrm{CO}$ and other content in a relatively small amount of synthesis gas in favor of simplifying the follow-up process. The using of steam gasification process in the world is very few, mainly used in laboratory research. The last century 80's, Professor Kunii, D. first dual fluidized bed gasification technology methods [1-3]. Packages are equipped with a

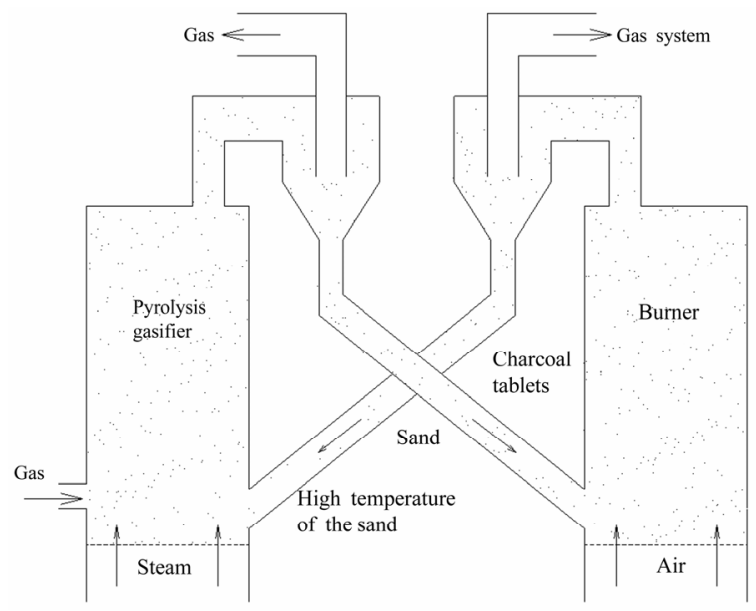

Figure 1. The gasifier of two fluidized beds of biomass.

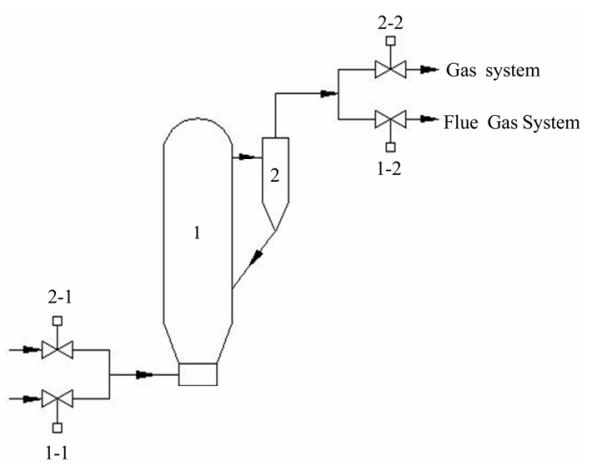

Figure 2. Single fluidized bed gasification two-step working principle, 1-1 Air control valve, 1-2 Flue control valve, 2-1 Steam Control Valve, 2-2 Gas Control Valve. fluidized bed gasifier and the composition of fluidized bed combustion furnace (Figure 1). Burner for heating air combustion of coke particles in the gasifier heating inert particles, while for the steam gasifier and high temperature so that biomass particles in the flow of inert state pyrolysis reaction occurs to produce hydrogen-rich synthesis gas. This method does not require external heat source, and therefore do not require oxygen equipment and low cost operation. However, due to the volume and temperature of heat carrier restrictions, not more than gasifier temperature of $800^{\circ} \mathrm{C}$, resulted in lower gasification efficiency, on the other hand, un-time as a result of coke and the heat carrier are at a high temperature cycle, it is difficult to quantitatively control, temperature easy to change, it is difficult to stable operation, restrictions on use of the fact that, at present there is no practical case of industrialization. Professor Wang Tongzhang, Jiangsu University, at the conclusion of the research team based on previous experience, in 1990 put forward a single fluidized bed by two-step gasification method. Synthesis gas was prepared with steam gasification agent. And obtained a patent in China [4,5]. Principle of the work of this process known as fluidized-bed water gas gasifier (FWG). The equipment with coal as raw materials has industrialized. With biomass as raw material the equipment being promoted in this paper technological processes of the gasification process, the scope of application and the moving results are introduced.

\section{A SINGLE FLUIDIZED BED TWO-STEP GASIFICATION PROCESS AND DEVICE [6]}

Water vapor and carbon for the gasification agent of raw materials to form $\mathrm{H}_{2}, \mathrm{CO}, \mathrm{CH}_{4}$ and $\mathrm{CO}_{2}$, the main reaction is:

$$
\begin{array}{cc}
\mathrm{C}+\mathrm{H}_{2} \mathrm{O} \rightarrow \mathrm{CO}+\mathrm{H}_{2} & -162.3 \mathrm{MJ} \\
\mathrm{C}+2 \mathrm{H}_{2} \mathrm{O} \rightarrow \mathrm{CO}_{2}+2 \mathrm{H}_{2} & -75.2 \mathrm{MJ} \\
\mathrm{CO}+\mathrm{H}_{2} \mathrm{O} \rightarrow \mathrm{CO}_{2}+\mathrm{H}_{2} & -43.56 \mathrm{MJ} \\
\mathrm{C}+2 \mathrm{H}_{2} \rightarrow \mathrm{CH}_{4} & +87.36 \mathrm{MJ} \\
\mathrm{C}+\mathrm{O}_{2} \rightarrow \mathrm{CO}_{2} & +408.86 \mathrm{MJ}
\end{array}
$$

Endothermic reaction is basically, in order to enable the reaction can be carried out, it is necessary to provide the necessary reaction heat. To this end will be in the same fluidized bed biomass gasification process is divided into two processes: First, the combustion process (the heating process); First, the process of pyrolysis and gasification. To the gasifier for combustion into the air and raw materials, so that flow of raw materials in a state of combustion heat release style (5), so that the material layer gasifier rapid increase in temperature is expected when the temperature rise to the scheduled (scheduled for $1000^{\circ} \mathrm{C}$ ), to stop for air, the end of the combustion process; gasifier turn to pyrolysis and gasification proc- 


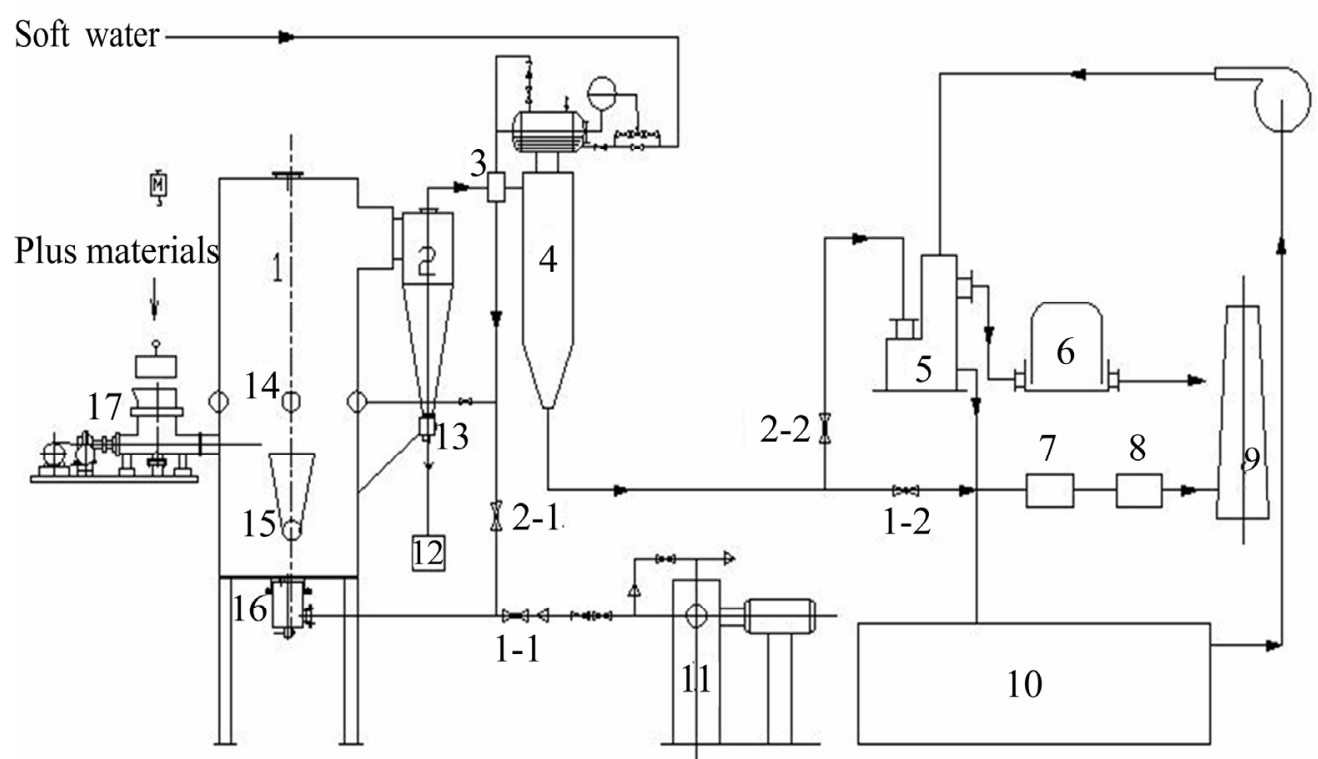

1 Fluidized bed biomass gasifier, 2 High-temperature cyclone, 3 Superheater, 4 Waste heat boile, 5 Scrubber, 6 Bell type gasholder, 7 Air preheater, 8 Precipitator(dust collector ), 9 Chimney, 10 Setting pond, 11 Roots blower, 12 Reserve gray box, 13 Feed back, 14 Air, steam nozzle, 15 Spiral feeding machine with biomass bunker, 16 Wind Room, 17 Spiral feeding machine with coal bunker.

Figure 3. The process flow of the water gas gasifier of fluidized bed of biomass.

ess, into the steam for the gasifier and biomass to biomass and the original high-temperature materials in the water vapor layer of the under the conditions in the flow of pyrolysis and gasification reaction occurred, resulting in the synthesis of $\mathrm{H}_{2}$-rich gas, because the process is endothermic reaction, the rapid temperature decline in bed when the bed temperature dropped to predetermined temperature (scheduled for the $900^{\circ} \mathrm{C}$ ), gasification process is over. The gasifier gets into the combustion process. The two processes repeated conversion to achieve the production of synthesis gas purpose. Two processes in the fluidized bed gasifier through imports and exports of two pairs of control valves: air control valve 1-1, vapor control valves 2-1 and Flue control valves 1-2, gas control valves 2-2 to achieve (see Figure 2) flue and gas, respectively, into the flue system and gas system, the gate valve by the furnace temperature control.

Figure 3 Biomass fluidized bed water gas gasifier (BFWG) process. Fluidized bed biomass gasifier (1) with two feeders, screw feeder biomass (15) and coal screw feeder (17) for the conduct of the total biomass and coal gasification, gasifier start when run-time, water vapor control valve 2-1 and gas control valve 2-2 to close, air control valve 1-1 and flue control valve 1-2 open when the combustion channels in working condition, when Roots blower (11) through the air control valve $1-1$ at the bottom of the wind from the gasifier chamber (16) for the first time into the air, at the same time coal screw machine (17) adding coal to the furnace (0 6mm), to enable complete combustion of fuel in the heater do, in the furnace equipped with a secondary air nozzle (14), secondary air jet from the nozzle to increase, so that paragraph into the suspension of particles of incomplete combustion of carbon and the gas composition to continue to burn, so that the furnace temperature the rapid increase in high-temperature combustion gas from the gasifier cyclone export to high temperatures, (2) after the beginning of dust into the superheater (3) and waste heat boiler (4) heat exchanger, the flue gas temperature to about $400^{\circ} \mathrm{C}$ below the flue control valve $1-2$ to enter the air preheater (7), flue gas temperature to $200^{\circ} \mathrm{C}$ the following into the dust collector (8), purified by the chimney (9) into the atmosphere. Under the high temperature cyclone separation carbon dust by the return feeder (13) returns to re-combustion gasification gasifier. When the furnace temperature up to set temperature $\left(1000^{\circ} \mathrm{C}\right)$, the end of the combustion process, when the air control valves, flue control valves $1-1$ and 1-2 followed by self-closing, steam control valve2-1 and gas control valve 2-2 automatically open one after another, from the waste heat boiler (4) water vapor generated by the steam superheater (3), the steam control valve 2-1 by the wind Room (16) into the gasifier, while biomass feeder (15) to adding biomass furnace $(0 \sim 10 \mathrm{~mm})$, then high-temperature material layer and adding biomass state in the flow of pyrolysis and gasification reaction occurred, resulting in hydrogen-rich gas. Since the reaction is endothermic reaction, the furnace temperature dropped quickly when the high temperature gas generated by cyclone (2) after the separation of carbon dust by 
the return under the feeder (13) into the re-gasification furnace, after the separation of crude gas into the waste heat boiler (4) for heat exchange cooling to below 400 ${ }^{\circ} \mathrm{C}$, the gas control valves, 2-2 to enter the scrubber tower (5), by the washing water after the cooling device into the gas cabinet (6),for users. When the furnace temperature down to set temperature $\left(900^{\circ} \mathrm{C}\right)$, the gasification process, steam control valves 2-1 and gas control valve 2-2 automatically shut down one after another, the air control valves1-1andflue control valves 1-2 followed by open, into the gasifier and the combustion process, alternating back and forth these two processes to work, production of the $\mathrm{H}_{2}$-rich syngas. Since the fluidized bed gasifier with a uniform temperature characteristic, temperature control in bed for two processes is not only conducive to the stability of production quality, and temperature can be arbitrary in order to obtain the synthesis gas components of satisfaction. General low-temperature limit determined by the reaction rate of raw materials, high temperature limit determined by the ash melting point of raw materials. Two waste heat recovery processes can be generated by steam gasification to meet their own needs.

\section{BIOMASS FLUIDIZED BED WATER GASIFIER IS RUNNING RESULTS AND ANALYSIS}

Biomass feedstock to $0 \sim 10 \mathrm{~mm}$ smash into the furnace, due to the shape of biomass particles of diversity, so that net flow of biomass is more difficult biomass powder usually include a certain amount of inert particles such as sand, to improve the Health the flow of material performance, as a result of China's coal-dominated energy structure, the authors selected coal $(0 \sim 6 \mathrm{~mm})$ in place of the inert particles, such coal to improve the flow of not only played the role of performance, because coal is a hot body, together with the biomass total gasification, coal and biomass in the physical and chemical properties of many complementary aspects, such as the coal density high, fixed carbon content high, ash melting point high, chemical activity low; and biomass density low, fixed carbon contentlow, ash melting point low, high volatile, highchemical activity and easy to gasification, gasification of the two were complementary to each other will receive such good results. Therefore this section will be a comprehensive discussion of this technology to coal, biomass gasification and the two kinds of co-gasication were the result of the operation [6].

\subsection{The Operation of Coal as Raw Materials Results}

Table 1 shows the results of the operation in the type FWG 1.6 gasifier.

The three kinds of coal in the long-term continuous operation, results showed that regardless of coal for the weak or strong adhesive bonding of all long-term stable operation and good results. The strong bond not only of coal coking phenomenon did not happen, and gas indicators are generally better than the weak bonding of coal, mainly air and water vapor at $950^{\circ} \mathrm{C}$ and above the turn of coal particles for combustion and gasification reactions, so that caking coal rapid destruction of the gluey layer, the strong bond of coal can be a smooth operation. Fluidized bed water gas gasifier is automatically adjustable, the results in Table 1 is a coal gasification process of running the results can be seen from the gas composition, gas composition in the $\mathrm{H}_{2}$ high, $\mathrm{CH}_{4}$ content is generally $5 \sim 7 \%$. The CO content of less than $20 \%$, which is due to the process of coal gasification, when there are complex reaction mechanism, when the water vapor and carbon bed water-gas reaction to produce high gas mixtures containing $\mathrm{H}_{2}$, has just joined the Fan coal in such a high temperature pyrolysis atmosphere makes reaction $\mathrm{CH}_{4}$ and $\mathrm{H}_{2}$ gas in a marked increase in the content, and some scholars believe that the main $\mathrm{CH}_{4}$ from the hydrogenation reaction (4).

Table 2. Different ways of coal feeding have an effect on gas composition. Coal feeding in different ways, from changing in gas composition obviously. In the process of coal gasification, coal is fed, the component of the $\mathrm{H}_{2}$ and $\mathrm{CH}_{4}$ in the gas increased obviously, while reducing $\mathrm{CO}$, for high volatile coal, the greater difference. This factor is a gasifier to provide a more convenient, that is, through different ways to increase coal output is suitable for the requirements of different gas components.

\subsection{Biomass as Raw Materials Moving Results}

Water fluidized bed biomass gasifier (BFWG) set up two feeders: biomass and coal screw feeders. Generally the gasifier was fed with biomass powder $(0-10 \mathrm{~mm})$ in the gasification process $(0 \sim 10 \mathrm{~mm})$, coal combustion process by adding $(0 \sim 6 \mathrm{~mm})$, this study used corncob, rice husk, wood chips as raw material, high in the inner diameter $300 \times 4000 \mathrm{~mm}$ bed water-gas gasifier in operation results (Table 3).

\subsection{Discussion and Analysis of the Results}

From the corn cob, sawdust, rice husk three experiments show that the agricultural and forestry waste (Table 4), The diversity of the types of biomass does not affect the performance of their gasification, the gas composition, calorific value, the efficiency of gasification, tar and other parameters in the same operating conditions, the results were similar. The results from Table $\mathbf{5}$ show that the impact of gasification temperature gasification gas production rate and efficiency of key parameters, (the technology can easily adjust the parameters), with the increase in transition temperature, gas production rate and a corresponding increase in efficiency gasification, 
Table 1. The results of three coal.

\begin{tabular}{|c|c|c|c|}
\hline The type of coal & Lean coal & Coke & Semi-anthracite \\
\hline \multicolumn{4}{|l|}{ Industry Analysis wt $\%$} \\
\hline Total Moisture & 8.11 & 7.8 & 3.37 \\
\hline Inherent moisture & 0.8 & 0.42 & 0.77 \\
\hline Fixed carbon & 65.37 & 53.94 & 56.42 \\
\hline Volatile & 13.66 & 14.53 & 18.62 \\
\hline Ash & 12.86 & 23.67 & 21.24 \\
\hline Sulfur content & 0.32 & 0.3 & 0.35 \\
\hline Calorific value of coal $\mathrm{KJ} / \mathrm{Kg}$ & 25103 & 23268 & 23040 \\
\hline Characteristics of coke residue & 3 & 6 & 4 \\
\hline Roca Index & Non-bonded & 75 & Weak bond \\
\hline \multicolumn{4}{|l|}{ Ash melting point $\left({ }^{\circ} \mathrm{C}\right)$} \\
\hline Deformation temperature & 1470 & $>1400$ & $>1200$ \\
\hline Softening temperature & 1500 & $>1400$ & $>1200$ \\
\hline Operating Temperature & $950 \sim 1000$ & $950 \sim 1000$ & $950 \sim 1000$ \\
\hline \multicolumn{4}{|l|}{ Gas composition vol\% } \\
\hline $\mathrm{CO}_{2}$ & 10.6 & 8.4 & 9.4 \\
\hline $\mathrm{CO}$ & 15.3 & 19.5 & 19.4 \\
\hline $\mathrm{H}_{2}$ & 61.12 & 59.5 & 58.81 \\
\hline $\mathrm{CH}_{4}$ & 6.83 & 6.9 & 6.92 \\
\hline $\mathrm{O}_{2}$ & 0.3 & 0.1 & 0.14 \\
\hline $\mathrm{N}_{2}$ & 5.58 & 5.7 & 5.63 \\
\hline $\mathrm{H}_{2} \mathrm{~S}\left(\mathrm{mg} / \mathrm{m}^{3}\right)$ & 120 & 120 & 120 \\
\hline tar content $\left(\mathrm{mg} / \mathrm{m}^{3}\right)$ & 3.3 & 3.3 & 3.3 \\
\hline Gas calorific value $\left(\mathrm{KJ} / \mathrm{m}^{3}\right)$ & 11201 & 11453 & 11227 \\
\hline Water gas production rate $\left(\mathrm{m}^{3} / \mathrm{Kg}\right)$ & 1.2 & 1.2 & 1.19 \\
\hline Gasification efficiency $\quad(\%)$ & 52 & 59 & 58 \\
\hline Thermal efficiency $(\%)$ & 85 & 85 & 85 \\
\hline
\end{tabular}

Table 2. Gas components under different coal feed ways.

\begin{tabular}{cccccccc}
\hline \multirow{2}{*}{ Operation Mode } & \multicolumn{9}{c}{ Gas composition } & \multicolumn{2}{c}{$\begin{array}{c}\text { Calorific value } \\
\left(\mathrm{KJ} / \mathrm{m}^{3}\right)\end{array}$} \\
\cline { 2 - 6 } & $\mathrm{CO}_{2}$ & $\mathrm{O}_{2}$ & $\mathrm{CO}$ & $\mathrm{CH}_{4}$ & $\mathrm{H}_{2}$ & $\mathrm{~N}_{2}$ & 9207 \\
\hline Combustion process feed coal & 17.5 & 0.3 & 17.9 & 2.06 & 58.13 & 4.11 & 10120 \\
Gasification process feed coal & 10.6 & 0.3 & 15.3 & 6.83 & 61.12 & 10.12 & 12 \\
\hline
\end{tabular}

Table 3. The industrial materials analysis and elemental analysis of the materials.

\begin{tabular}{|c|c|c|c|c|c|c|c|c|c|}
\hline \multirow{2}{*}{$\begin{array}{l}\text { Types of raw } \\
\text { materials }\end{array}$} & \multicolumn{4}{|c|}{ Industry Analysis/\% } & \multicolumn{4}{|c|}{ Elemental analysis/\% } & \multirow{2}{*}{$\frac{\text { Calorific value }}{\text { Q KJ/Kg }}$} \\
\hline & $\mathrm{M}_{\mathrm{t}}$ & $\mathrm{A}_{\mathrm{ar}}$ & $\mathrm{V}_{\mathrm{ar}}$ & $\mathrm{FC}_{\mathrm{ar}}$ & $\mathrm{C}_{\mathrm{ar}}$ & $\mathrm{H}_{\mathrm{ar}}$ & $\mathrm{N}_{\mathrm{ar}}$ & $\mathrm{O}_{\mathrm{ar}}$ & \\
\hline Corncob & 5.6 & 6.24 & 76.92 & 11.24 & 47.63 & 4.91 & 0.85 & 46.61 & 17245 \\
\hline Sawdust & 13.44 & 1.42 & 75.91 & 9.23 & 46.18 & 6.28 & 0.14 & 47.4 & 15672 \\
\hline Rice husk & 7.4 & 11.01 & 73.78 & 7.81 & 45.13 & 5.04 & 0.76 & 49.07 & 14557 \\
\hline Test Coal & 4.7 & 26.5 & 7.94 & 60.86 & 62.31 & 2.86 & 1.02 & 1.9 & 23120 \\
\hline
\end{tabular}


Table 4. Moving results of biomass.

\begin{tabular}{cccc}
\hline Item & Corncob & Sawdust & Rice husk \\
\hline The amount of biomass kg/h & 140 & 140 & 140 \\
The amount of coal $\mathrm{kg} / \mathrm{h}$ & 35 & 35 & 35 \\
Biomass/Coal & $4 / 1$ & $4 / 1$ & $4 / 1$ \\
Air for combustion stage & 270 & 270 & 270 \\
For the amount of water vapor gasification stage $\mathrm{kg} / \mathrm{h}$ & 110 & 110 & 110 \\
Steam/Biomass $(\mathrm{S} / \mathrm{B})$ & 0.79 & 0.79 & 0.79 \\
Operating temperature range ${ }^{\circ} \mathrm{C}$ & $900-950$ & $900-950$ & $900-950$ \\
Gas composition $(\mathrm{Vol} \%)$ & & & 38.6 \\
$\mathrm{H}_{2}$ & 38.87 & 37.78 & 32.70 \\
$\mathrm{CO}$ & 32.29 & 30.23 & 7.73 \\
$\mathrm{CH}_{4}$ & 11.62 & 9.43 & 13.41 \\
$\mathrm{CO}_{2}$ & 13.7 & 14.88 & 0.4 \\
$\mathrm{O}_{2}$ & 0.2 & 0.8 & 7.7 \\
$\mathrm{~N}_{2}$ & 7.32 & 6.88 & 11496.24 \\
Gas calorific value $\mathrm{KJ} / \mathrm{m}^{3}$ & 12579 & 11766.3 & $<10 \mathrm{mg}$ \\
content of tar oil $\mathrm{mg} / \mathrm{m}^{3}$ & $<10 \mathrm{mg}$ & $<10 \mathrm{mg}$ & 1.1 \\
Gas production rate $\mathrm{m}^{3} / \mathrm{kg} \mathrm{daf}$ & 1.15 & 1.17 & 86.80 \\
Gasification efficiency $\%$ & 84 & 88 & 85 \\
Gasification intensity $\mathrm{kg} /\left(\mathrm{m}^{2} \mathrm{~h}\right)$ & 85 & 3000 & \\
\hline thermal efficiency of gasifier $\%$ & & &
\end{tabular}

Table 5. Corncob interval at different temperatures of the test results.

\begin{tabular}{cccc}
\hline & \multicolumn{3}{c}{ Temperature range $\left({ }^{\circ} \mathrm{C}\right)$} \\
\cline { 2 - 3 } Item & $850-900$ & $900-950$ & $950-1000$ \\
\hline The amount of biomass $\mathrm{kg} / \mathrm{h}$ & 120 & 120 & 120 \\
The amount of coal $\mathrm{kg} / \mathrm{h}$ & 30 & 30 & 30 \\
Biomass/Coal & $4 / 1$ & $4 / 1$ & $4 / 1$ \\
Air for combustion stage $\mathrm{m}^{3} / \mathrm{h}$ & 286 & 286 & 286 \\
For the amount of water vapor gasification & 108 & 108 & 108 \\
stage $\mathrm{kg} / \mathrm{h}$ & 0.9 & 0.9 & 0.9 \\
Steam/Biomass $(\mathrm{S} / \mathrm{B})$ & & & 46.30 \\
Gas composition $(\mathrm{Vol} \%)$ & 28.70 & 38.30 & 28.30 \\
$\mathrm{H}_{2}$ & 26.10 & 29.40 & 8.40 \\
$\mathrm{CO}_{\mathrm{CH}}$ & 19.7 & 11.20 & 10.50 \\
$\mathrm{CO}_{2}$ & 18.20 & 13.70 & 0.4 \\
$\mathrm{O}_{2}$ & 0.4 & 0.2 & 6.1 \\
$\mathrm{~N}_{2}$ & 6.0 & 7.20 & 0.7 \\
content of tar oil mg/m & 1.20 & 0.9 & 1.25 \\
Gas production rate $\mathrm{m}^{3} / \mathrm{kg} \mathrm{daf}$ & 1.00 & 1.20 & 12043 \\
Gas calorific value $\mathrm{KJ} / \mathrm{m}^{3}$ & 14315 & 12414 & 87.3 \\
Gasification efficiency $\%$ & 83 & 86.4 & \\
\hline
\end{tabular}


Table 6. The current production methods of medium-heating value compared with the technique.

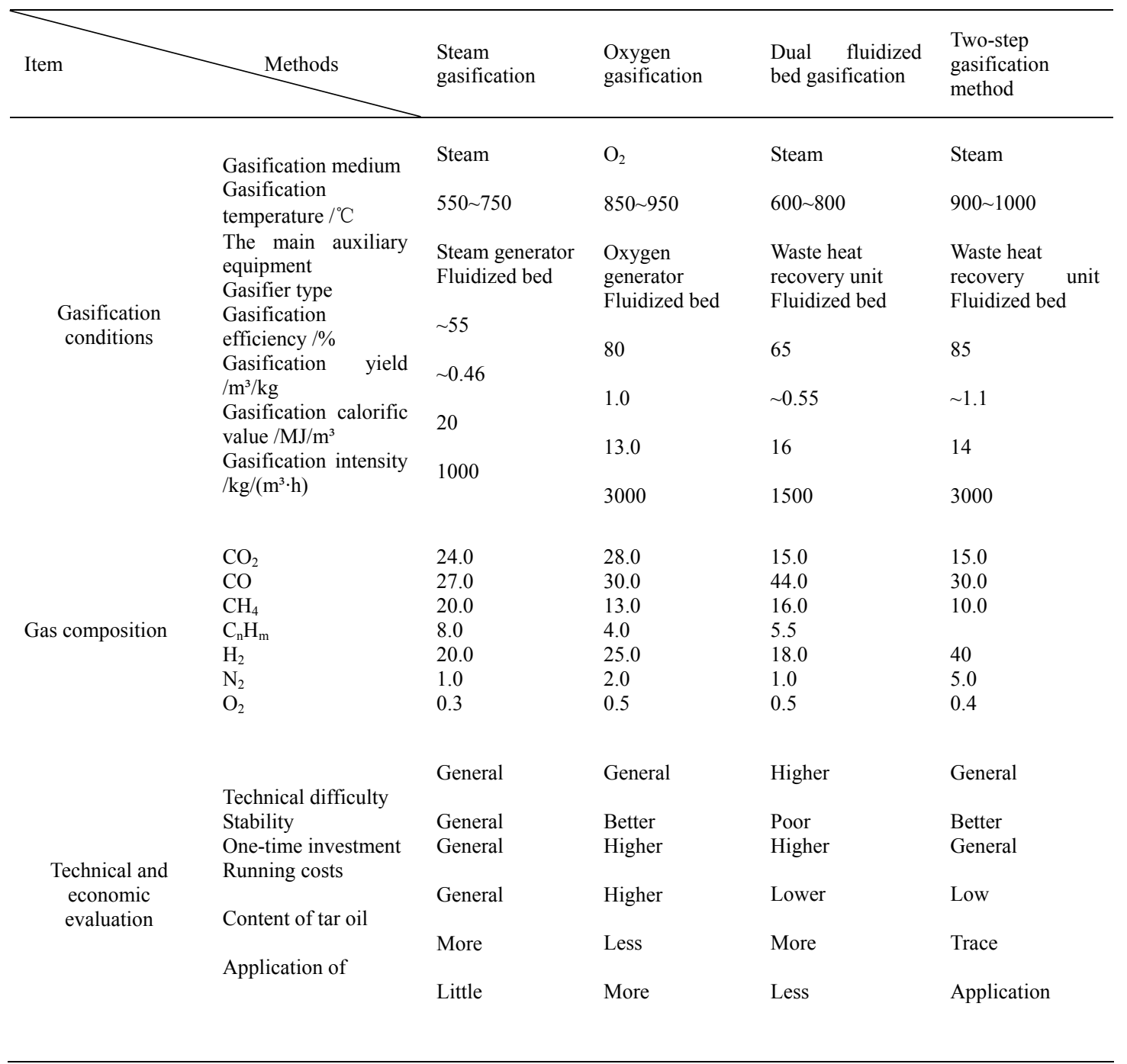

Table 7. 10,000 tons / year to estimate the scale of investment in manufacturing plant (equipment).

\begin{tabular}{clc}
\hline Serial number & \multicolumn{1}{c}{ Item } & Total (Million) \\
\hline 1 & $\begin{array}{l}\text { Part of biomass gasification (prepare feed、Gasifier、Purification } \\
\text { Storage cabinets,Counter to the gas purification) }\end{array}$ & 1000 \\
2 & Fine desulfurization 、 Dechlorination & 95 \\
3 & Compression Section & 130 \\
4 & Synthesis of dimethyl ether & 210 \\
5 & Distillation of dimethyl ether & 50 \\
6 & Electrical instrumentation & 130 \\
7 & Other & 100 \\
Total & & 1715 \\
\hline
\end{tabular}

and gas heat values increase with the transition temperature decreased. $\mathrm{H}_{2}$ is mainly expressed in the increase as the temperature increases, and decreases due to CH4. S/B is the impact of gas composition, gas yield and gas calorific value of the important parameters in Figure
4 that the gas temperature of $900-950^{\circ} \mathrm{C}$, corn cob/coal ratio of $4 / 1$, gas $\mathrm{H}_{2}, \mathrm{CH}_{4}, \mathrm{CO}$ content and $\mathrm{S} / \mathrm{B}$ relationship. As well as gas production rate and the $\mathrm{S} / \mathrm{B}$ relationship (Figure 5), gas heat value and the S/B relationship. (Figure 6). 
Table 8. Estimates of consumption of fixed costs (per ton of DME).

\begin{tabular}{cccccc}
\hline Serial number & Name & Units & Amount & Units (yuan) & Amount (yuan) \\
\hline 1 & Straw & $\mathrm{t}$ & 4.4 & 200 & 880 \\
2 & Coal & $\mathrm{t}$ & 1 & 400 & 400 \\
3 & Electricity & Kwh & 600 & 0.5 & 300 \\
4 & Water & $\mathrm{t}$ & 300 & 0.2 & 60 \\
5 & Steam & $\mathrm{t}$ & 1.5 & 60 & 90 \\
6 & Catalyst & $\mathrm{Kg}$ & 2.5 & 40 & 100 \\
7 & Subtotal & & & & 1830 \\
8 & Other & & & & 500 \\
9 & Cost of sales & $\mathrm{t}$ & & & 2330 \\
\hline
\end{tabular}

As can be seen from the chart, in the experimental conditions, the gas content in $\mathrm{H}_{2}$ increases with the $\mathrm{S} / \mathrm{B}$ increasing, and $\mathrm{CH}_{4}, \mathrm{CO}$ content both reduces with the $\mathrm{S} / \mathrm{B}$ increasing.

\section{CONCLUSION AND OUTLOOK}

\subsection{Conclusion}

Fluidized bed biomass gasifier water and put into service, after a long-term operation test, indicating that the stability of the furnace is running, convenient operation, stable performance. In this paper, biomass and coal ratio under different experimental results show the feasibility of gasification technology and economic advantages (Table 6). The results from the pilot to see in biomass synthesis gas preparation methods, this technology has the following characteristics.

1) Applies to a wide range of raw materials: agricultural and forestry waste and organic solid waste can be used effectively. Biomass as a result of agriculture, forestry, raw material suppliers subject to seasonal changes,

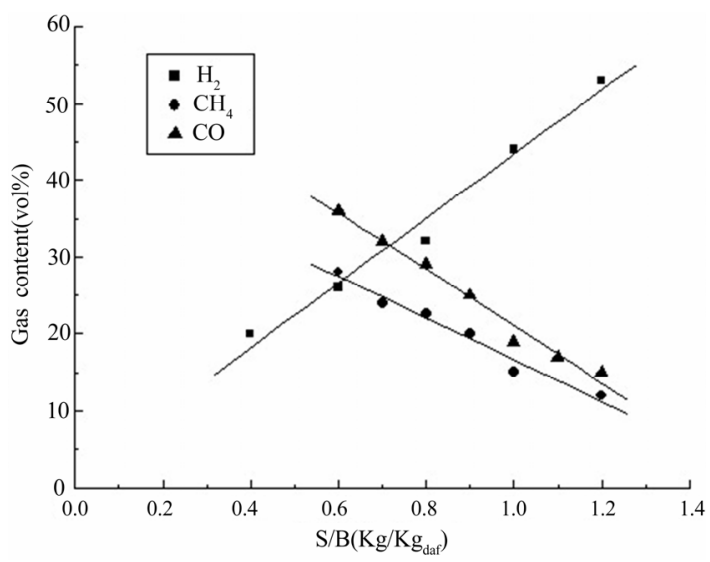

Figure 4. The influence to the $\mathrm{H}_{2}, \mathrm{CH}_{4}$ and $\mathrm{CO}$ percents of the product gas by the value of $\mathrm{S} / \mathrm{B}$. can be adjusted to ensure that the coal to security of energy supplies.

2) This technology is particularly applicable to a total of coal and biomass gasification. A result of coal in the combustion process can be quickly obtained by adding the necessary high-temperature gasification process and heat conditions. So the process of biomass gasification

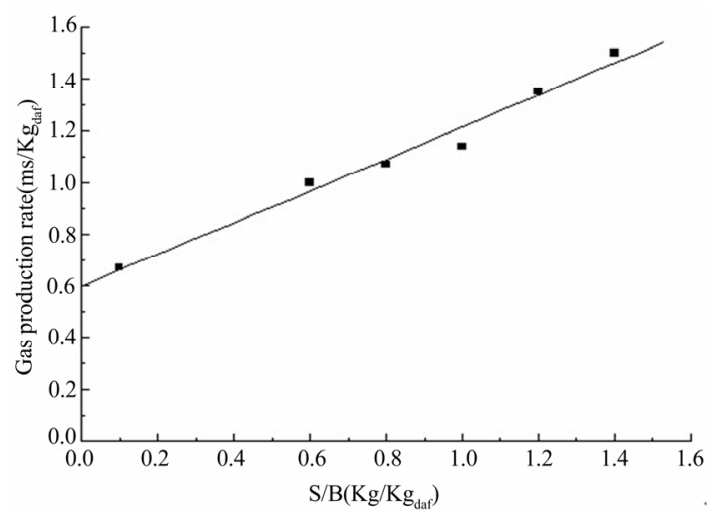

Figure 5. The influence to the yield of the product gas by the value of $\mathrm{S} / \mathrm{B}$.

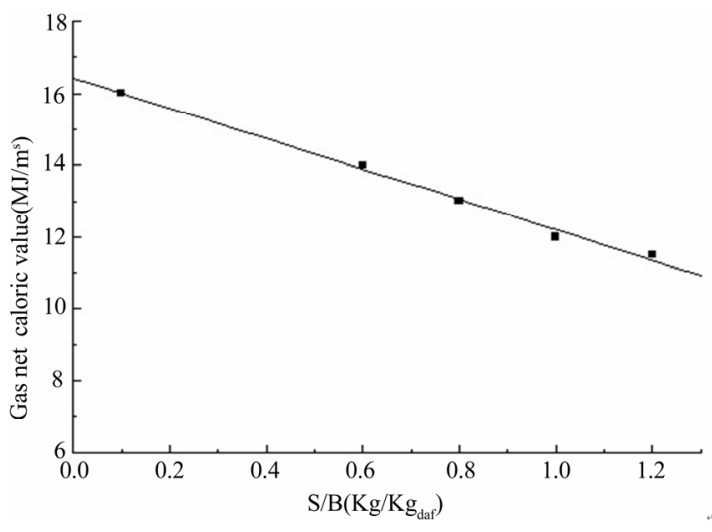

Figure 6. The influence to the heat value of the product gas by the value of $\mathrm{S} / \mathrm{B}$. 
has been transformed into efficient. Due to high temperature, the role of water vapor in the gas under very low tar content, so easy to deal with gas purification, resolved biomass gasification gas with high tar problems.

3) High levels of $\mathrm{H}_{2}$ gas, $\mathrm{H}_{2}+\mathrm{CO}>70 \%, \mathrm{H} / \mathrm{CO}=1 \sim 2$, is a synthetic alcohol fuel components suitable for the synthesis of alcohol fuel, the preparation of $\mathrm{H}_{2}$ technology to provide a viable route.

\subsection{Outlook}

The development and utilization of oil alternatives and renewable sources of energy is the world's largest energy development trends and hot, renewable energy, the biological resources into liquid fuels to replace oil with other types of energy unparalleled advantage. At present, many countries in the corn to sugar cane as raw material, through the biological alternative fuel ethanol into gasoline has been noticed, as the existing technology of powdered sugar to starch-based, people struggle with food concerns, has been transferred to wood cellulose as raw materials on behalf of the Section 2 the development of biomass fuels. Due to technical and economic reasons, the second generation of fuel ethanol industry takes time. Even cellulose as raw materials process technology, the future level of industrialization can be achieved. Due to the diversity of straw cellulose, in the production process we also need to deal with the residue. In this paper, the biomass gasification technology is more perfect to deal with these types of materials technology. Biological ferment and gasification methods both integrated development, to make the development and utilization of biomass energy achieve better results. Technology is now under the operation of indicators, the production of 1 ton each of dimethyl ether (DME), the need for 4.4 tons of straw and 1 ton of coal. China based on the current market price, 200 yuan per ton of straw,400 yuan per ton coal, it is estimated the technology ton DME production plant of economic indicators. (Table 7, Table 8)

Taking into account the cost of capital, a total investment of about 3000 million, at current market price of DME 5,000 yuan per ton, production of 1 2 years to recover their investment. The technology of biomass for hydrogen production, due to purification, separation technologies are mature technologies [7-9], $1 \mathrm{~kg}$ of hydrogen to be consumed $12 \mathrm{~kg}$ of straw plus $3 \mathrm{~kg}$ of coal. renewable energy technology in the economic advantage. As a result of this two-step technique, in the production process, about half the time the combustion process will be used to provide heat for the gasification process, the line considerable. The calorific value of hydrogen is the fuel units 3 times, which can be seen the application of The resulting hydrogen can be projected cost per ton of about 4,000 5,000 yuan. This is the current cost of gaso same-size models of fluidized-bed gasifier for gasification than oxygen for gasification agent law, and its production capacity will be less $1 / 2$. However, due to the biomass distribution of a wide set shipped difficulties and is not suitable for large-scale production. This small-scale production plant, built near the highway to the highway for the trunk to form a supply network, so that raw materials can be extensive and products combine the mobility of, do the local sales of local production.

A wide range of biomass distribution of a large amount of earth each year, the total biomass (dry) of about 1400-1800 billion tons, equivalent to the annual world energy consumption 10 times the biomass wish for the adoption of this technology to do economic development of mankind a contribution.

\section{REFERENCES}

[1] J. corella, J. M .Toledo, and G. Molina, (2007) A review on dual fluidized-bed biomass gasifiers. [J] Ind. Eng .Chem .Res., 46, 6831-6839.

[2] J. corella, J. M. Toledo, and G. Molina, (2008) Biomass gasification with pure steam in fluidized bed. [J] Int, J. Oil., Gas and coal Technology, 1(1/2).

[3] C. Z. Wu, B. Y. Xu, Z. F. Luo, et al. (1995) Analysis of biomass gasification for MHV fuel gas. [J]. Coal Gas and Heating Power, 15(2), 8-14.

[4] T. Z. Wang, L. Q. Wang, and H. S. Zhou, A king of biomass and coal co-gasification method and derice of the fluidized bed, 4, CN200410013943.

[5] T. Z. Wang and L. Q. Wang, A kind of water gas gasification method and device, ZL90105680.

[6] L. Q. Wang, X. Song, H. S. Zhou, et al. (2008) Development study on co-gasification of biomass and coal in fluidized bed gasifier. (II) $[\mathrm{J}]$ Acta Energiae Solaris Sinica, 29(3), 354-359.

[7] D. L. Xie, G. Y. Yi, Z. W. Li, W. Y. Qiao, (2007) Selection of fluidzed bed technology for hydrogen production from biomass gasification. [J] Sino-global Energy. 12, 20-24.

[8] S. T. Turn, Z. Zhang, et al. (1998) An experiment investigation of hydrogen production from bimass gasification. [J] Int. J. Hydrogen Energy., 23(8), 641-648.

[9] X. Y. Su, Z. W. Wang, C. M. Cheng, et al. (2000) Study on biomass pyrolysis and gasification in a fluidized bed [J] Jounal of Fuel Chemistry and Technology, 28(4), 298-305. 